\title{
Economic Integration In ECOWAS: 40 Years After
}

\author{
Michael P. Okom, Associate Professor Lecturer \\ Faculty of Law, University of Calabar, Calabar, Nigeria
}

doi: 10.19044/esj.2016.v12n19p75 URL:http://dx.doi.org/10.19044/esj.2016.v12n19p75

\begin{abstract}
The Economic Community of West African States (ECOWAS) was launched in Lagos on 28 May, 1975, amidst fanfare and big dreams of economic nirvana: economic integration, development and prosperity. The template for the institutional mechanisms and infrastructure for the realization of the dreams were encapsulated in the Treaty itself and the relevant Protocols. The legal and institutional framework presented a picture perfect structure which only needed concerted and focused action, to realize ECOWAS' lofty goals and objectives. 37 years after, this still remains a mirage. This paper examines the cause for this untoward status-quo and proffers ideas as to how the drive towards the actualization of the ECOWAS as a viable, virile, economic bloc can be attained.
\end{abstract}

Keywords: ECOWAS, Economic development, economic integration

\section{Introduction}

The main goal of the ECOWAS was the economic integration of the region as reflected in the 1975 ECOWAS Treaty thus: "It shall be the aim of the Community to promote co-operation and development in all fields of economic pactivity...for the purpose of ... increasing and maintaining economic stability... and ... contributing to the progress and development of the African continent." ${ }^{, 13}$ In order to attain that goal, the Member States were required to, among other things, harmonise their economic and industrial policies and eliminate the disparities in the level of development of the Member States. ${ }^{14}$ To enable the ECOWAS to facilitate this objective, a Trade, Customs, Immigration, Monetary and Payments Commission was set up. ${ }^{15}$

The Treaty laid the foundation for a robust intra-regional trade regime by prescribing parameters for liberalisation of trade, such as a

\footnotetext{
${ }^{13}$ Article 1.

${ }^{14}$ Article 1 (2) (f).

${ }^{15}$ Art. 4 (e).
} 
Customs Union, Common Tariff treatment for community goods, et al. ${ }^{16}$ The Revised Treaty which came into effect in 1993 reemphasised pungently that "the aims of the Community are to promote cooperation and integration, leading to the establishment of an economic union in West Africa, in order to raise the living standards of its people and maintain and enhance economic stability"? The Community was to ensure the harmonisation of national policies in the areas of trade, money finance et al. The Community was also to promote joint ventures by private sector enterprises and other economic operators in particular through the adoption of cross-border investments. It was also to adopt measures for the integration of the private sectors, particularly the creation of an enabling environment to promote small and medium scale enterprises.

\section{Pre-1975 regional undercurrents}

The issue of global and regional integration has always be in the front burner of international politics. As early as 1965, the Economic Commission for Africa (ECA), "in a tireless effort, organized four meetings throughout Africa, with a view to building viable economic groupings in each of the four sub-regions of Africa." ${ }^{\prime 7}$ They were held in Lusaka (1965), in Brazzaville, Tangiers, and Niamey in 1966. The Niamey meeting was the first to be attended by all the West African States, who merely agreed that a "Project of Association" be embarked upon, "enlarging existing areas of eo-operation."18 A Conference followed in Accra Ghana ${ }^{19}$ which called for the removal of trade barriers between African countries "as rapidly as possible." 20

In 1964, Nigeria and Togo, which had a long history of political intercourse, signed an agreement in 1964 which "removed visa requirements placed on the movements of the citizens of the two States by their respective governments". ${ }^{21}$ In 1966, the two countries entered into a trade agreement whose goal was the generation of maximum trade between the two countries, characterized by a covenant to promote and develop trade in compliance with the laws and regulations in force in each of the States. They also agreed that in order to enhance commercial intercourse;

\footnotetext{
${ }^{16}$ Articles 12 -26.

${ }^{17}$ R. Onwuka, Development and Integration in West Africa; ECOWAS, Ife: University of Ife Press, 1984, p. 60.

${ }^{18}$ Ibid.

${ }^{19}$ Attended by all except the Gambia and Guinea, April 27 - May 4, 1967.

${ }^{20}$ R. Onwuka, op. cit., p. 61.

${ }^{21}$ Nigeria's Treaties in Force, V. 1; Lagos, Federal Ministry of Information, Printing Division, 1971, p. 25. On the same day, Nigeria also "exchanged notes" with Cameroun, Chad, Dahomey, Ivory-Coast, Niger and Morocco, abolishing visa requirements. Nigeria exchanged similar notes with Guinea less than one year later.
} 
The contracting parties also agreed to furnish each other on request, all necessary information concerning the possibilities of supplying goods and commodities originating form their respective territories. They also contracted to grant freedom of transit of commercial goods originating in the territory of one of them and transported over the territory of the other. ${ }^{22}$

A few years later, Nigeria concluded trade agreements with seven neigbouring countries in the West African sub-region and economic cooperation agreements with five. ${ }^{23}$ Between 1971 and 1973, Nigeria and Togo, who had emerged as clear leaders of the movement for integration developed a scheme of action which 15 States met to discuss in $1973 .^{24}$ The States agreed to set up the required institutional structures for a Community and possible areas of cooperation, as well as the "taxonomies and nature of various levels of integration”. ${ }^{25}$ Later that year, a Draft ECOWAS Treaty was drawn up in Lome, Togo, with the assistance of the ECA, after which a second ministerial meeting was convened in Niamey, Niger, in March 1974 to deliberate on it. Later that year, it was adopted in Liberia and submitted to the Heads of State Conference in Lagos on May 28 1975, where it was signed by eleven Heads of State and four Plenipotentiaries ${ }^{26}$ and became the ECOWAS Treaty. A revised version was to follow in 1993, which had 37 more articles. $^{27}$

\section{ISSUES STILL AT STAKE}

The ECOWAS Treaty, Revised Treaty and specifically, the Protocols on Free Movement held so much promise for the future economic prosperity of the region that was to come via integration. Cross-border movement has

${ }^{22}$ Ibid.

${ }^{23}$ Okoi Arikpo, in a lecture delivered at the Nigerian Institute of External Affairs, titled “Nigeria and the O.A.U.”, 31 July 1974, pp. 11 - 12.

${ }^{24}$ The fifteen States were: Benin, Ivory Coast, Cape Verde, Burkina-Faso, The Gambia, Ghana, Guinea, Liberia, Mali, Niger, Nigeria, Senegal Sierra - Leone, Togo and Guinea Bissau, (which was attending for the first time).

2514 Onwuka, op. cit., p. 69.

${ }^{26}$ The eleven Heads of State who signed the Treaty were: Mathew Kerekou, (Dahomey); Dauda Jawara, (The Gambia); Liuiz Cabral, (Guinea - Bissau); Felix Houghphet Boigny, (Ivory Coast); William Tolbert, (Liberia); Moktar Duld Daddah, (Mauritania); Seyni Kountche, (Niger); Yakubu Gowon, (Nigeria); Siaka Stevens, (Sierra - Leone); Gnassingbe Eyadema, (Togo); A. Anguole Lamizana, (Upper Volta). The four Plenipentiaries were from Ghana, Guinea, Mali and Senegal.

${ }^{27}$ Social affairs, Women Development, Settlement of Disputes, ECOWAS and other Regional Economic Communities, Amendments and Revisions and Withdrawal. 
been a time tested means of extenuating the effects of poverty and economic declension.

As stated by the Sahel Club, "migration and mobility within the region and beyond are populations’ prime strategy against poverty”. ${ }^{28}$ The club further opines that:

Regional trade, be it informal or "official", is the major grassroots integration driver. There are no significant statistics on the annual volume of regional trades on the types of goods traded, on exchanges between areas... Regional trade operators, whatever their size have denounced legal and illegal barriers that hinder free circulation (illegal "tolls"). They have appealed to the States to apply the law. ${ }^{29}$

One reason for this, which virtually all concerned stakeholders are agreed on, is the lack of political will on the part of Member States to implement the provisions of the Treaty/Protocols on Free Movement of Goods and Capital. In his keynote address at the international marketing ECOWAS' $30^{\text {th }}$ anniversary, ${ }^{30}$ Professor Jerry Gana. ${ }^{31}$ Expatiating on the lack of political will as the reason for past failure stated that "African governments were unwilling to subordinate their domestic political and economic interests to supranational institutions with long term regional goals". ${ }^{32}$ Mike Obadan and Peter Egbon agree. In their words,

The will to integrate is very much shaky... The lack of political will and commitment to implement community decisions has been a major stumbling block to integration efforts. At the level of the Authority of Heads of State,

there is every indication of political commitment during ECOWAS summit meetings. But the political input at the national level tapers off soon after. ${ }^{33}$

They point out that the ambivalence exhibited by ECOWAS countries on the issue of political will weakens the ECOWAS' standing in

\footnotetext{
${ }^{28}$ Medium and Long-term Regional Development Perspectives in West Africa, (symposium held for the $30^{\text {th }}$ Anniversary of the Economic Community of West African States, ECOWAS, Abuja (Nigeria), 25 and 26 May 2005), Edited by the Sahel Club, p. 58. 29 Ibid.

${ }^{30}$ Held in May 2006, Abuja with the theme, ECOWAS: Milestones in Regional Integration: Daily Champion Newspaper, May 30, 2006, p. 40.

${ }^{31}$ The former Nigerian Minister for Integration and Cooperation in Africa.

${ }^{32}$ Daily champion, op. cit. (See note 62).

${ }^{33}$ West African Regional Economic integration: Nigerian Policy Perspectives for the 1990s, Nigerian Institute of International Affairs, (NIIA), Publication 1994, p. 55.
} 
the international arena. ${ }^{34}$ They posit that while the political will and commitment to sub-regional groupings and international organisations that compete with ECOWAS are high, the same is lacking in the broader ECOWAS grouping. ${ }^{35}$ It is this lack of political will that is the reason why Member States are often so loud about cataloguing the illegalities and improprieties at the borders but maintain a stance of dignified inaction year in year out.

In January 2007, the AHSG expressed concern over the "numerous obstacles still existing along West African highways and at the borders of ECOWAS Member States"36 They urged Member States to take all necessary measures to implement the Protocol on Free Movement and directed the ECOWAS Commission to "ensure the completion of the remaining portions of international highways and interconnection of railway networks with standard gauge”. The members of the AHSG being directly responsible for the implementation of the Protocols, are merely shirking from responsibility by merely expressing concern and directing Member States to do it. It is merely a diplomatic way of consigning the ECOWAS Protocols to the”Keep In View, (KIV) cabinet.

The ECOWAS 2008 Report acknowledged that harassment on ECOWAS highways and borders was still an issue to be tackled. It states thus:

In the bid to eliminate road harassments, (the) ECOWAS Commission embarked upon reflection with technical partners for the establishment of an electronic registration system at border entry and exit points... A regional integrated border management programme is under negotiation with the European Union. This programme will help modernize border control posts and thus reduce time loss and racketeering. ${ }^{37}$

This perennial dependence on foreign help has become a subterfuge for inaction, political negligence and ineptitude in governance. All forms of sophisticated gadgetery can be placed at the borders but if they are manned by the same corrupt and extortionist officials, the situation will not change. It could even worsen because those personnel could render those gadgets out of use within days and return to business as usual because of having aclimatised to the regime of unaccountability and institutionally ingrained racketeering.

\footnotetext{
${ }^{34}$ Ibid.

${ }^{35}$ Ibid.

${ }^{36}$ Rescheduled Summit in Onagadougou, Burkina -Faso

${ }^{376}$ P. 77.
} 


\section{Surmounting the challenge and actualising the vision of integration}

The experience of ECOWAS demonstrates that Treaty making goes beyond summits, fanfare and numerous Protocols. The goals of ECOWAS are salutary and if achieved could create an economic mini nirvana for the people whose economic well- being the Treaty/Protocols seek to uplift. To date, ECOWAS has not delivered on its agenda and the verdict, which is virtually unanimous amongst stakeholders is that the ECOWAS ship of State is still rigmaroling at the shore still looking forward to commencing its voyage. What constitutes ECOWAS today are the AHSG Summits, (a siren blowing fiesta), conferences, seminars and workshops, with piles of paper work. While all this is going on, the stakeholders and peoples await practical action. The authors avers that ECOWAS can work in accordance with a new agenda.

The AHSG has to adhere to the pacta sunt servanda rule, by which treaties are binding on the parties and must be performed in good faith. This principle is enshrined in Article 26 of the Vienna Convention on the Law of Treaties, which States that "every treaty in force is binding upon the parties to it and must be performed by them in good faith". With respect to the ECOWAS Treaty, the disposition of the parties as the evidence copiously shows, demonstrates that the parties are all in breach of Article 26 of the Vienna Convention.

Demonstration of good faith in the view of the author, would be to comply with the provisions of the Protocol on Free Movement of Goods and Capital expeditiously. The long delay in keeping faith with the Protocol can be atoned for if the parties awake to the realities of the NWIEO in the area of economic integration. The attitude of the parties in clinging so tenaciously to their sovereignty, negates the pacta sunt servanda rule. The author contends that fear of loss of sovereignty is unfounded because in the long term, whatever sovereignty is sacrificed would elicit benefits in the long term, in terms of expanded trade, access to a larger market and a boost in productivity as the private sector stretches to utilise the opportunities of the common market and favourable tariff regimes. The tenacious clinging to sovereignty in order to avoid integration is only beneficial to the political leadership of the region. The people will benefit more from integration because of the increased economic opportunities, by way of new jobs, prosperity and a better "standard of living of its peoples... (and) economic stability." 38 The surrender of a little sovereignty for the purpose of strengthening the ECOWAS' suprationality, is a worthwhile price to pay for all these benefits.

According to I.O.S. Nwachukwu, at its formation, ECOWAS held a lot of promise as one of the dynamic strategies through which economic

${ }^{38}$ Article 2, 1975 Treaty. 
underdevelopment could be surmounted and the all pervading poverty in the sub-region eliminated. ${ }^{39}$ This assumption was based on the unique size of the Community with its large population which was to serve not just as a means for the mobilisation of internal resources for industrialisation but also as a powerful attraction for the inflow of foreign investment.

From the experience of the EU, the Caribbean Community (CARICOM), the East African Community (EAC) and others, regional integration is undoubtedly arduous, but need not take 37 years to manifest. In Nwachukwu's words, "the truth is that integration would only proceed well where the Member States

are prepared to make sacrifices on different levels." ${ }^{40} \mathrm{He}$ added that "it is now evident that renewed energies are required and new paths cultivated, if a new lease of life was to be given to the Community for its optimal performance." ${ }^{41}$

For these "new paths" to be charted, a new agenda has to be drawn up, with the ECOWAS Commission playing a key role. The Commission should move beyond just whining and writing reports to play a robust and activist role. The Commission was established to make ECOWAS function properly. In order to do this, it should partner with the media to highlight cases of breach of the Treaty/Protocols and place them in the front burner of public discourse within the region. The Commission should thus cease to be a mere bureaucratic institution but a spirited driver of the integration process. The issue of sanctions has to be visited. States should not breach the Protocol without some form of sanctions ranging from suspension to payment of heavy fines. In a situation where all the parties are guilty, this might be difficult, but the Commission, in collaboration with the media, Civil Society and other stakeholders can make this a prime item on the agenda of the AHSG.

Civil Society, NGOs and human rights activists have a big role to play. They should sponsor cases of human rights abuses by operators of the Protocols. Victims of harassment and extortion can also take class action which the media in the region should not take off their front pages and prime time for as long as the cases last. Thankfully, the ECOWAS Court of Justice has now granted access to private individuals, as opposed to the previous status-quo, when only State parties had access to the Court, as enshrined in Article 9(3) of the Protocol of the Court. ${ }^{42}$

${ }^{39}$ G. O. Obiozor, (ed.), op. cit., p. xi.

40 Ibid, p. xii.

${ }^{41}$ Ibid.

${ }^{42}{ }^{74}$ Protol A/p1/7/91 
In Afolabi Olajide v. Federal Republic of Nigeria ${ }^{43}$, the Court ruled that the applicant, who had lost a huge amount of money because his goods were stranded at the Nigeria/Benin Republic border due to its closure by the Nigerian Government, could not bring an action before it, by virture of Article 9(3) of the Court's Protocol. According to Anthony Anene - Maidoh, Olajide's case "made it clear that the limited scope of the jurisdiction of the court, and denial of access... to individuals were grave and amount to the fundamental limitation of the rights of... West African individuals." 44 The President of the corut, Justice Hansine Donli after delivering the judgment urged formulators of the Act to broaden its scope to enable individuals to bring actions before the Court. ${ }^{45}$

In the case of Frank Ukor V. Rachad Lalaye, ${ }^{46}$ the Court on the same grounds, truck out the Plaintiff/Applicant's meritorious action with respect to seizure of his truck and the goods therein, the order having been made by a Cotonou Court of first instance in January 2004. However, a Supplementary Protocol was enacted in 2005 which granted access to individuals, in compliance with the Court's plea. Article 4 of the Supplementary Protocol amended the Protocol of the Court by inserting a new Article 10 which states in Article 1, (d), that "Access to the court is open to individuals on application for relief for violation of their human rights..." With respect to the

International law rule that exhaustion of local remedies is a requirement before recourse to international tribunals, the rule of the court is that it is not a requirement under the Community texts.

In the case of Hadijatou Mani Koraou v. Republic of Niger, ${ }^{47}$ the applicant took advantage of the new rules by successfully bringing an action for violation of her human rights. She had been sold to a man who used her both as a slave and a concubine and when she escaped, she brought this action in which the Court ruled in her favour and awarded her ten million francs in damages. It is submitted that under the new rules, Olagide and Ukor would succeed. Individuals, Civil Society, NGOs and victims of abuse should take advantage of these new rules and apply judicial pressure on the organs of ECOWAS to become more pragmatic, and committed to the ideals of the Treaty/Protocols.

\footnotetext{
${ }^{43}$ Case no- ECW/CCJ/04/2004

${ }^{44}$ Jurisdiction of the Community Court of Justice, ECOWAS, Paper by the Chief Registrar of the Court, During the Court's sensitisation mission to Calabar, Cross River State, Nigeria, from March 4 - 10, p. 4.

${ }^{45}$ Vanguard Newspaper, 28 April, 2004.

${ }^{46}$ Case no - APP/01/04, 17 March, 2005.

${ }^{47}$ Case no. ECW/CCJ/APP/11/07.
} 
In order for this to happen, public enlightenment must be done in a sustained and widespread manner. This should be carried to markets, schools and motor parks where cross border travellers throng, and airports. Fliers should be distributed to commuters, and cross border traders. Such fliers should provide capsule information on human rights and access to justice. If people are well informed, they will be empowered to seek redress when they encounter breaches. For example, a trader whose goods are unduly detained at the border for refusal to succumb to extortion could reek redress and if the culprits are punished and the media publicises these events, it will go a long way towards making commuting easier and integration possible.

After 40 years, a regional organisation should not have teething problems or be taking baby steps as is the case with ECOWAS. It is now cluttered with many bureaucracies,: (WAMI, WAMZ, EMCP, EBID, WAMA, et al) to oversee economic integration alone. So much money is being spent with minimal results. The 2008 report is not cheering:

The year 2008 marks the second year of the transformation of the Executive Secretariat into a Commission... This process repositions the institutions of the ECOWAS on the march towards the realization of the ECOWAS vision..., which embodies the long - term aspiration of the Community- the transformation from an ECOWAS of States to an ECOWAS of people. ${ }^{48}$

It reveals that the Commission commenced laying the building blocks for the structures and institutions required to shoulder the challenges of realising the vision with a significant augmentation of the staff strength. ${ }^{49}$ In other words, more money is to be spent and there are little or no indications as at the time of this writing that results are within sight. The 2008 Report says ECOWAS is "on the march" towards the realization of the ECOWAS vision. In 2003, the Executive Secretary's Report indicated that the leadership of the region "is gradually fusing the... countries in the region into a single state.." 50

If this were so, in 2008, ECOWAS should not have been "marching". It ought to have attained some level of success. Now, ECOWAS has fixed 2020 as the year of realisation of integration, ${ }^{51}$ just 8 years away. Unless it has a magic wand or an open seseme talisman in one of its cabinets, judging by what is on the ground today, even 2020 seems surreal.

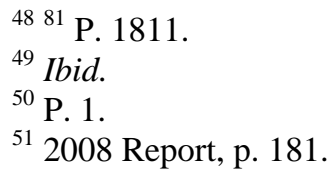


The ECOWAS realises that democracy, political stability and security are necessary for sustained economic development, ${ }^{52}$ which in turn creates a conducive atmosphere for integration. No one wants to integrate with a person whose house is on fire. The region is just coming out of conflict in Sierra-Leone and Liberia. Nigeria today is plagued by the severe security challenge posed by Boko Haram. The region is currently embroiled in the Guinea - Bissau coup crisis. Allied to this, the sit-tight syndrome of African leaders is threatening security in Benin, Niger and Senegal. Democracy has not found welcome climes in Africa. The result is that while such leaders are in office, the controversies that surround their ascendancy make them to harness all their energies, time and resources towards in retaining power. Thus, most of their attention is on domestic issues, leaving little or no time to attend to regional matters.

\section{Conclusion}

The peculiar situation in the various ECOWAS countries should not be allowed to capsize the ECOWAS boat. The leaders of the region must be attuned to the fact that the political will to move beyond the nation State is a vital pre-requisite to attaining some minimal degree of regional cooperation. As far as the author is concerned, a more serious will is needed to achieve integration and the genuine regional unity that was envisioned by the founding fathers of the ECOWAS in order to fast track the integration process and take the peoples of the region to the "nirvana" the Founding Fathers Promised in the preamble to the 1975 and Revised Treaty.

In this era of increasing regionalism, integration is the recipe for the region to have a strong presence in Africa and the world. This will augur better for the region than to continue as a "balkanized West Africa."53

As former military President of Nigeria, Ibrahim Babangida has so aptly surmised:

ECOWAS is the answer to the (West African)

Predicament of colonial balkanization. It is the remedy to the anomaly whereby our principal trading partners continue to be the metropolitan European powers, as opposed to our neighbors. Within the ECOWAS dream lies the firm promise of a selfreliant and economically integrated West Africa, able to chart its destiny on the basis of economic equality with the developed countries. ${ }^{54}$

\footnotetext{
${ }^{52}$ Ibid, p. 183.

${ }^{53}$ G. O. Obiozor, (ed.), op cit., p. 134.

${ }^{54}$ Nigeria's then Military President, Ibrahim Babangida's speech at the

ECOWAS Conference in Senegal. (Quoted in G. O. Obiozor, (ed.), op. cit., p. 134
} 
Chimelu Chime, Integration and Politics Among African States: Limitations of Mid-Term Theorizing, Uppsala; Scandinavian Institute of African States Press, 1977.

\section{References:}

Daily Champion Newspaper, (Nigeria).

ECOWAS Report 2008.

ECOWAS Executive Secretary`s Report, 2003.

G. Obiozor et al, (ed.) Nigeria and the ECOWAS Since 1985: Towards a Dynamic Regional Integration, Nigeria Institute of International Affairs, Lagos: Fourth Dimension Publishers, Enugu, 1991.

G. Modelski, A Theory of Foreign Policy, London: Pall Mall, 1961.

International Monetary Fund (IMF) Annual Report on Integration in Africa. Ibn Chambas, Bottlenecks of ECOWAS Trade Liberalisation Scheme, The Comet Newspaper, July 2004.

Nigeria`s Treaties in Force, Federal Ministry of Information, Printing Division, 1971.

Okoi Arikpo “Nigeria and the O.A.U.’' Lecture Delivered at the Nigerian Institute of External Affairs, July 311974.

O.A.U. Report on Forum for Promotion of Financial Market of Integration and Development in Africa, 1997. (Article by A. Ekpe on “Financial Market Integration and the Private Sector: The view from the Banking Sector"').

O.J Nnanna, Seminar on ECOWAS Common External Transt, Dec. 2005, The Comet Newspaper, Jan 4, 2006.

Papers Presented at the 2005 Programme Implementation and Technical Review Meeting, by the Department of Planning, Research and Statistics of the Ministry of cooperation and Integration (MCIA) July, 2005.

P. Masson and C. Pattilio, "Monetary Union in West Africa, (ECOWAS): Is it Desirable can it be Achieved"', www.inf.org. (2004, Last Visited 10-5-15).

Louis Sohn, Documents of African Regional Organisations, (Vol.3 1972.)

M.T. Ladan, Introduction to ECOWAS Community Law and Practice: Access to Justice, Peace and Security, Zaria; Ahmadu Bello University Press, 2009. In

R. Onwuka, Development and Integration in West Africa: ECOWAS, Ife: University of Ife Press, 1984.

Revised Treaty of ECOWAS

R. Lawrence (ed.), Regional Integration and Cooperation in West Africa: A Multi-Dimensional Perspective, Ottawa U.S.A. World Press, 1997.

Sahel Club, (ed.), Symposium on Medium and Long-Term Regional Development Perspectives in West Africa during the $30^{\text {th }}$ Anniversary of ECOWAS, Abuja, (Nigeria), 2005.

Thisday Newspaper, July 16, 2008. 
U.S. Bureau of African Affairs Fact Sheet on ECOWAS.

Vanguard Newspaper, April, 2004 (Nigeria).

Wikipedia.org/wiki.

West Africa Regional Economic Integration: Nigerian Policy Perspectives for the 1990s, Nigerian Institute of International Affairs Publication, 1994. 